\title{
Memória, educação e cidadania - Tecendo 0 cotidiano de creches e pré-escolas em Itupeva-SP.*
}

\author{
Maria Isabel Leite** \\ Sonia Kramer***
}

Trata-se de livro - realizado pela Prefeitura Municipal de Itupeva (SP) e pelo Centro de Memória da Unicamp - que apresenta um instigante e vivo relato da história do município, particularmente relativa às classes de creches e pré-escolas lá existentes. Explicita-se, no livro, assim, o próprio processo de construção da proposta e da formação continuada de seus professores, aspecto fundamental, a nosso ver, para toda intervenção educacional que se proponha a efetivamente iniciar mudanças e garantir a continuidade e a legitimidade de conquistas feitas.

Um dos pontos positivos, do livro e da proposta, refere-se ao fato de ser um trabalho que traz, para o campo da educação infantil, uma interessante contribuição, rara na nossa área, que ressalta a dimensão cultural da vida das crianças e dos adultos com os quais convivem. Mais do que um trabalho de fora para dentro, trata-se de uma escrita que resgata a participação dos diferentes atores presentes no município, escapando de uma visão escolar ou pedagogizante da infância. Aponta, dessa maneira, uma possibilidade concreta de que as crianças aprendam com a história vivida e narrada pelos mais velhos. O objetivo principal do trabalho de "aproximar pais e filhos, estimular o diálogo, o contar histórias, valorizando tal conhecimento" (p. 25) parece-nos, portanto, ter sido plenamente alcançado.

* Resenha do livro de Park, Margareth Brandini. Memória, educação e cidadania - Tecendo o cotidiano de creches e pré-escolas em Itupeva - SP. Campinas, CMU, 1996.

** Professora do Curso de Especialização em Educação Infantil: Perspectivas de trabalho em creches e pré-escolas da PUC-Rio e doutoranda da Faculdade de Educação da Unicamp.

*** Professora do Departamento de Educação da PUC-Rio e coordenadora do Curso de Especialização em Educação Infantil: Perspectivas de trabalho em creches e pré-escolas desta universidade. 
Vale destacar também o envolvimento das várias instâncias da comunidade. Nesse sentido, a metodologia empregada, fazendo uso de histórias de vida e especialmente de fotografias acompanhadas de relatos orais, apresenta-se como fonte legítima de reconstituição da história do município em seus múltiplos aspectos. São tratados temas tais como a evolução dos meios de transporte, em especial o significado do trem, a assistência à saúde, os meios de comunicação, o desenvolvimento econômico em geral, as festas e a religiosidade manifesta e a caracterização dos bairros. As diversas pessoas que contam suas experiências relativas a esses temas construíram essa história em muitos de seus diferentes momentos; ao contá-las elas revelam, trazendo o passado, um outro olhar do próprio presente. Por outro lado, esse movimento de reconstituição culmina com a exposição de fotos, relatos escritos e objetos, evento que propicia também uma nova releitura das trajetórias vividas. Como aparece no depoimento de uma das professoras, o momento da exposição representa "a coroação do trabalho, pois minha avó era indispensável àquelas fotos e documentos, pois ela deu-lhes vida" (p. 32).

Por fim, cabe dizer que, no processo de ir tecendo o cotidiano vivido nesse município, delineia-se uma alternativa importante de rastreamento da história. Os textos escritos produzidos, as fotos e os relatos aqui reunidos apresentam uma possibilidade metodológica de trabalho não só em cidades que têm uma similaridade com o município de Itupeva, como também oferecem-se como um instrutivo exemplo de trabalhos que podem ser desencadeados em comunidades menores, em áreas rurais ou bairros de periferias de regiões urbanas e, neste aspecto, reside talvez o seu maior valor. 